\title{
Endocrine tumour in kidney affecting small bowel structure, motility, and absorptive function ${ }^{1}$
}

\author{
M. H. GLEESON, S. R. BLOOM, J. M. POLAK, K. HENRY, AND \\ R. H. DOWLING
}

From the Departments of Medicine, Morbid Anatomy, and Histochemistry, Royal Postgraduate Medical School and Hammersmith Hospital, London, and the Department of Medicine, Middlesex Hospital, London

SUMMARY A 44-year-old woman is described with an endocrine tumour arising in the kidney. There were associated abnormalities of small intestinal morphology, motility, and absorptive function. These abnormalities reversed on removal of the tumour. Detailed studies showed that the tumour contained, and was secreting, glucagon. It is postulated that the intestinal abnormalities may have resulted from glucagon itself or another, as yet unidentified, hormone.

Glucagon-secreting tumours are rare and the few cases described have, with one exception, arisen in the pancreas (Gössner and Korting, 1960; Unger, Lochner, and Eisentraut, 1964; Yoshinaga, Okuno, Shinji, Tsujii, and Nishikawa, 1966; McGavran, Unger, Recant, Polk, Kilo, and Levin, 1966; Vance, Kitabchi, Buchanan, Stoll, Hollander, and Wood, 1968). The exception was a case reported by Unger et al (1964), who demonstrated glucagon in the metastases of an anaplastic bronchogenic carcinoma.

The purposes of the present paper are twofold: (1) to report a glucagon-secreting tumour arising in the kidney, and (2) to describe a previously unrecognized association, that of altered small bowel structure, motility, and absorptive function, apparently due to the renal tumour since these intestinal changes promptly disappeared after nephrectomy.

\section{Materials and Methods}

\section{INTESTINAL FUNCTION}

Protein-losing enteropathy was estimated by measuring faecal radioactivity for four days after intravenous ${ }^{51} \mathrm{CrCl}$ (van Tongeren and Majoor, 1966). Faecal fat excretion was measured by the van de Kamer technique (van de Kamer, ten Bokkel Huinink, and Weyers, 1949) and was the mean of two three-day collection periods on a fixed $70 \mathrm{~g}$ dietary fat intake $(N<6 \mathrm{~g} /$ day $)$. Vitamin $B_{12}$

${ }^{1}$ Presented in part at the annual meeting of the British Society of Gastroenterology, November, 1970 (Gut, 1970, 11, 1060, abstract). Requests for reprints to R.H.D.

Received for publication 27 July 1971. absorption was measured by the urinary excretion method (Schilling, 1953): normally it is $>10 \%$ of dose excreted/24 hours.

Urinary indican excretion was measured in 24hour urine samples by the method of Curzon and Walsh (1962): normal is $<100 \mathrm{mg} / 24 \mathrm{hr}$.

Urinary xylose excretion was measured over five hours following a $25 \mathrm{~g}$ oral load (Helmer and Fouts, 1937).

\section{THE TUMOUR}

\section{Light microscopy}

Portions of the tumour were fixed in formol mercury, and $10 \%$ neutral formol saline. Chromaffinity was assessed in Orth's fixed material.

The paraffin-embedded formol mercury and neutral-formol-saline-fixed material was variously stained with haematoxylin and eosin (H \& E), Bodian's silver stain, Schmorl's and Diazo methods, Masson's trichrome, phosphotungstic acid haematoxylin (PTAH), periodic-acid-Schiff technique (PAS), Gomori's aldehyde fuchsin, and thioflavine T. Frozen sections were stained with oil red $\mathbf{O}$ and PAS.

\section{Electron microscopy}

Further portions of the tumour were fixed immediately after nephrectomy in $3 \%$ gluteraldehyde in cacodylate buffer. The tissue was postfixed in $1 \%$ osmium tetroxide and embedded in Epon 812. Sections were stained with uranyl acetate and lead citrate and examined in an AEI 801 electron microscope. 


\section{Histochemistry}

The methods used were essentially the same as previously described (Rost, Polak, and Pearse, 1969). Two blocks of tissue were quenched in Arcton 22 (Freon 22), one for freeze drying followed by exposure to formaldehyde vapour to investigate fluorogenic amine content (Table I), the other for cryostat sections to stain for enzymes which are usually present in endocrine polypeptide producing cells.

Another feature of cells of the endocrine polypeptide series (called APUD cells by Pearse (1969) from the initial letters of their staining characteristics) (Table I) is their uptake of amine precursors (5-HTP and DOPA) which was tested in vitro (Table I).

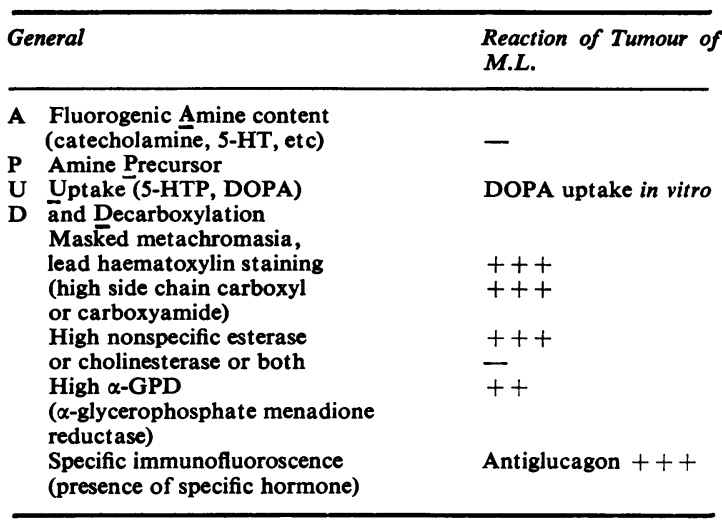

Table I Cytochemical characteristics of polypeptide hormone-secreting cells and of kidney tumour in patient M.L.

To confirm the presence of secretory granules, tumour blocks were fixed in $6 \%$ gluteraldehyde in

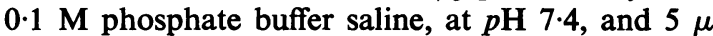
sections stained (Table I). In addition, since tryptophan is found in some endocrine polypeptide hormones, including glucagon, this amino acid was investigated with Lillie's xanthydrol method (Solcia, Sampietro, and Capella, 1969).

\section{Immunofluorescence}

The tumour was also examined for polypeptide hormone production by an indirect immunofluorescence technique (Coons, Leduc, and Connolly, 1955) using specific antisera (Table I). Details of tissue processing, the controls used, and the technique for globulin extraction from antisera were the same as those previously used to demonstrate polypeptide hormones in different gastrointestinal tissues (Polak, Coulling, Doe, and Pearse, 1971; Polak, Bloom, Coulling, and Pearse, 1971).

\section{ANTISERA}

The globulin fractions of the antisera which were used in the immunofluoroscence studies were prepared as follows:

\section{Gastrin}

Rabbit antisynthetic human gastrin (kindly supplied by Professor Rees).

\section{Calcitonin}

Rabbit antihuman calcitonin $M$ (prepared by Professor Iain MacIntyre).

\section{Growth hormone}

Rabbit antihuman growth hormone.

$A C T H$

Rabbit antihuman ACTH.

Insulin

Guinea-pig antihuman insulin (anti-ACTH and antiinsulin sera kindly supplied by Dr B. A. L. Hurn, The Wellcome Research Laboratories).

\section{Glucagon}

The same glucagon antiserum (prepared by one of us-S.R.B.) was used both for immunofluorescence and for radioimmunoassay. There was no cross reaction between this antiserum and rabbit antisynthetic procine secretin (Polak, 1971).

For controls the above antisera were absorbed with an excess of the appropriate antigen.

\section{RADIOIMMUNOASSAY AND BIOASSAY}

The glucagon activity of both tumour and preoperative plasma was measured by radioimmunoassay (Albano and Elkins, 1970) using a rabbit antiporcine pancreatic glucagon antiserum (B10) and crystalline porcine pancreatic glucagon standards (Novo batch B69). Incubation damage was minimized by the addition of aprotinin (F.B.A. Pharmaceuticals) and antibody-bound and free hormone separated with dextran-coated charcoal.

The glucagon activity in a $20 \%(\mathrm{w} / \mathrm{v})$ saline homogenate of the tumour was also assayed biologically using $200 \mathrm{~g}$ Porton rats. After a two-hour control period, during which baseline blood samples were obtained from a carotid artery cannula, $0 \cdot 1 \mathrm{ml}$ of tumour extract was injected into the external jugular vein of the rats and further arterial blood samples were taken three, six, 10 , and 20 minutes later.

Plasma glucose was estimated using glucose oxidase (Technicon AutoAnalyzer) and plasma immunoreactive insulin was assayed using Wellcome MR58 antiserum and rat insulin standard (Novo R169). 


\section{The Patient}

\section{HISTORY}

The patient, a 44-year-old German housewife, ${ }^{1}$ was first seen at Hammersmith Hospital in September, 1969, complaining of polyuria and nocturia which had been present for one year. She had also complained of constipation for many years which had increased over the preceding six months. During the three months before admission she had noticed generalized oedema which had been gradually increasing. For three weeks before admission she had been nauseated and had occasionally vomited. During the subsequent course of her illness she developed amenorrhoea and loss of scalp hair. There was also a transient erythematous skin rash.

\section{CLINICAL EXAMINATION}

There was moderately severe generalized pitting oedema. The other positive findings were confined to the abdomen which was markedly distended. There was minimal free fluid present and large concrements of hard faeces were easily palpable. However, there was no enlargement of liver, spleen, or kidneys, and examination of other systems was unremarkable.

\section{Investigations}

\section{HAEMATOLOGY}

Initially, the $\mathrm{Hb}$ was $11.9 \mathrm{~g} / 100 \mathrm{ml}$ with a white cell count of $8,000 / \mathrm{c} \mathrm{mm}$ and a normal differential. There were hypochromic changes in the blood film, and the serum iron was reduced at $29 \mu \mathrm{g} / 100 \mathrm{ml}$ with a total iron-binding capacity of $300 \mu \mathrm{g} / 100 \mathrm{ml}$. On several occasions the ESR was in the region of $90 \mathrm{~mm} / \mathrm{hr}$ (Westergren).

During her subsequent illness there was an episode of Coombs-negative haemolytic anaemia which regressed spontaneously after two months.

\section{BIOCHEMISTRY}

Plasma urea and electrolytes were normal. Serum albumin ranged from 1.8 to $2.0 \mathrm{~g} / 100 \mathrm{ml}$, globulins were $1.5 \mathrm{~g} / 100 \mathrm{ml}$.

\section{LIVER FUNCTION AND STRUCTURE}

Serum bilirubin, alkaline phosphatase, and lactic dehydrogenase levels were all normal. Isocitric dehydrogenase was 23 IU (normal 3-8 IU); bromsulphalein retention was $27 \%$ at 45 minutes. A liver scan was normal as was a percutaneous needle (Menghini) biopsy of the liver, except that mitotic figures were unusually prominent.

\footnotetext{
${ }^{1}$ Kindly referred by Dr Pollard, Essex County Hospital.
}

\section{RENAL FUNCTION}

There was no proteinuria (24-hour urine protein nil on two occasions). Urine microscopy showed no red blood cells but occasional pus cells were found and, on culture, the urine grew occasional $E$. coli. The endogenous creatinine clearance was $143 \mathrm{ml} / \mathrm{min}$.

\section{INTESTINAL FUNCTION}

Mild steatorrhoea had been found at Essex County Hospital (faecal fat $8 \mathrm{~g} / 24$ hours), which was confirmed at Hammersmith Hospital (faecal fat $20 \mathrm{~g}$ / $24 \mathrm{hr}$ ).

Urinary xylose excretion was normal-10.8 g/5 hours. The glucose tolerance test, rather than indicating malabsorption, showed a mildly diabetic pattern, the fasting blood sugar of $70 \mathrm{mg} / 100 \mathrm{ml}$ rising to $215 \mathrm{mg}$ at one hour and falling to $120 \mathrm{mg}$ at two hours and $82 \mathrm{mg} / 100 \mathrm{ml}$ at two-and-a-half hours.

There was no evidence of protein-losing enteropathy, only $1.4 \%$ of a dose of intravenous ${ }^{51} \mathrm{CrCl}$ being excreted over a four-day period. Urinary indican excretion, however, was markedly raised$560 \mathrm{mg} / 24$ hours.

The Schilling test showed vitamin $\mathbf{B}_{12}$ malabsorption both without ( $1.5 \%$ excreted/24 hours) and with $(1.7 \%)$ intrinsic factor.

INTESTINAL STRUCTURE

A barium enema showed obvious faecal retention but the colon was otherwise normal. However, on barium follow-through the small intestine was grossly abnormal (Fig. 1a), being dilated with coarse, thickened mucosal folds. Intestinal transit was slow, the barium taking 14 hours to reach the colon. There was also a marked increase in calibre of the intestine, with an average diameter of jejunum of approximately $50 \mathrm{~mm}$, the upper limit of normal being less than $30 \mathrm{~mm}$ (Laws, Booth, Shawdon, and Stewart, 1963).

\section{Progress and Treatment}

The persistence of structural and functional small bowel changes led to a laparotomy on 22 January 1970.

\section{LAPAROTOMY FINDINGS (MR MANTOUDIS)}

The pelvic organs, liver, and spleen were normal and by that time there was no ascites. The main abnormality was marked hypertrophy and oedema of the small bowel wall which was present along the whole length of the small intestine but was more obvious in jejunum than in ileum. A full-thickness biopsy was taken from mid-jejunum. Again, there was gross retention of faeces in the colon. 


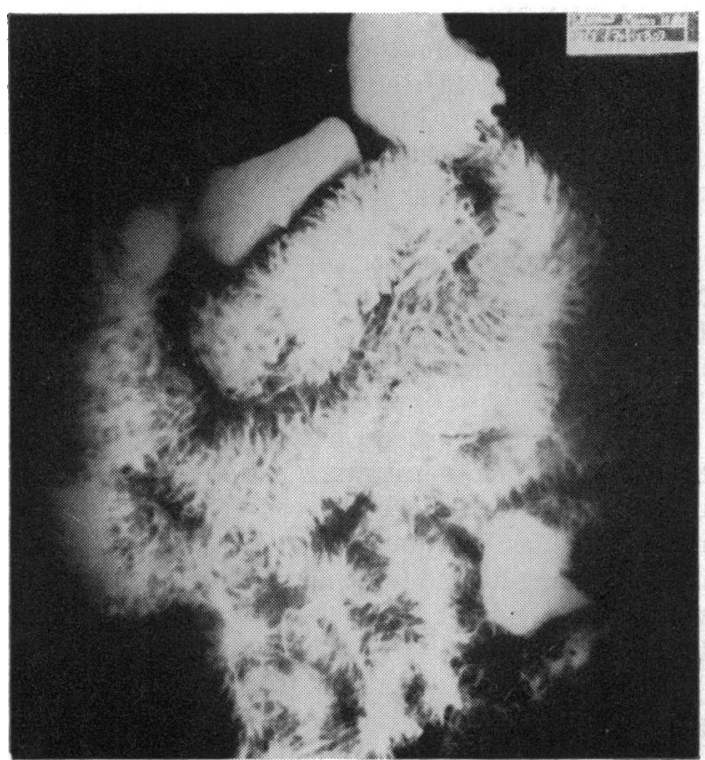

Fig. 1a Before nephrectomy the intestine shows marked increase in calibre with thickening of mucosal folds.

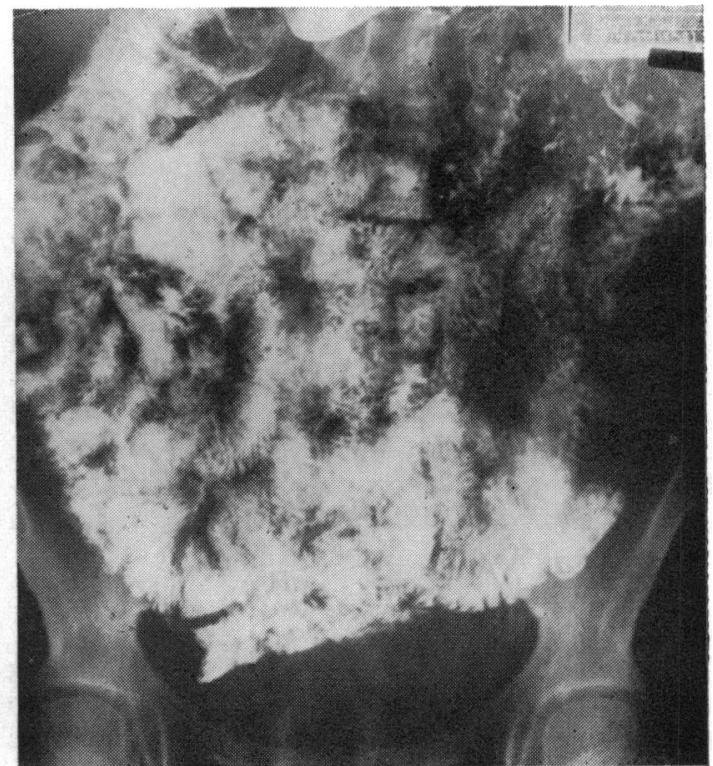

Fig. 1b Three weeks after nephrectomy the intestine shows normal diameter and normal mucosal pattern.

Fig. 1 Small bowel follow-through.

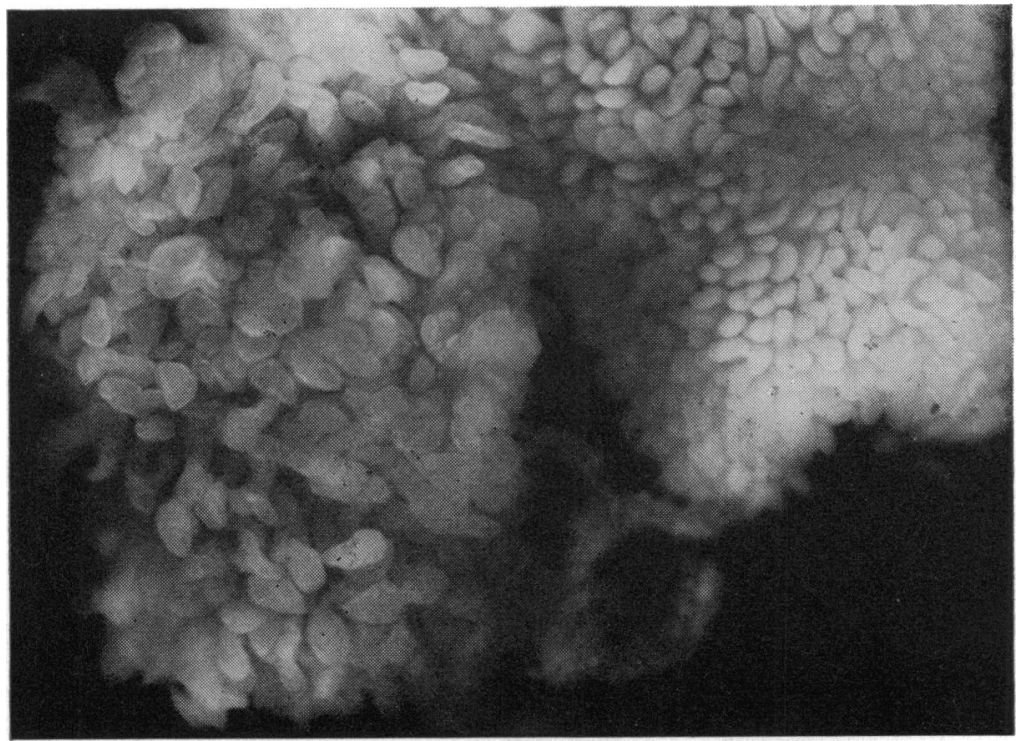

Fig. 2 Dissecting microscopic appearance of surgical biopsies of mid-jejunum $(\times 12)$. On the left is the biopsy from patient showing villous enlargement when compared with a 'control biopsy' taken from a similar site in the jejunum of a normal patient. (Both biopsies photographed simultaneously in the same microscope field.) 


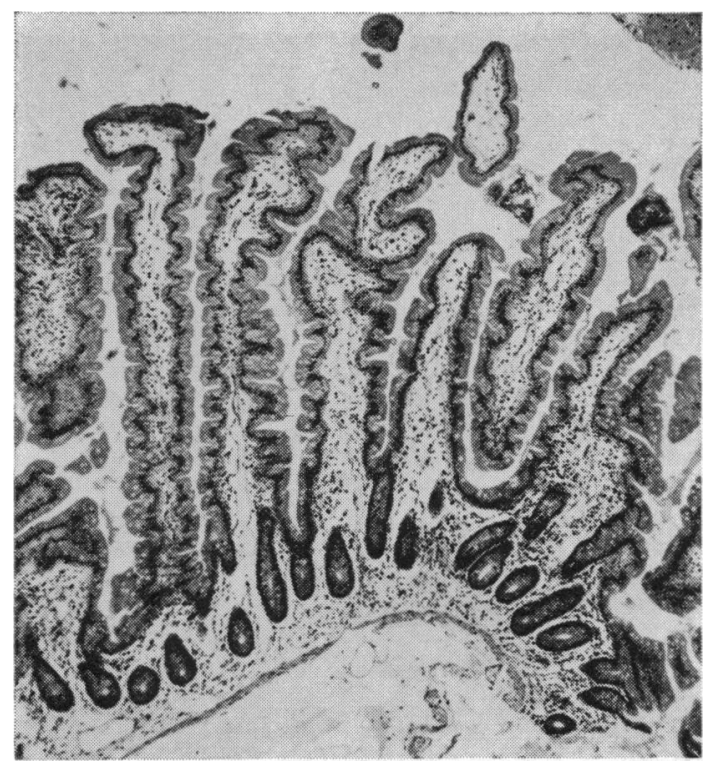

Fig. 3 Histology of surgical biopsy of jejunum showing tall slender villi measuring up to $1,350 \mu(H \& E \times 60)$.

\section{SURGICAL BIOPSY OF JEJUNUM}

The most remarkable feature was hypertrophy of the villi, which were easily visible to the naked eye-an appearance confirmed on dissecting microscopy (Fig. 2). In well orientated histological sections runs of villi measured (with a micrometer eyepiece) on average $1,150 \mu$ with occasional villi (Fig. 3) measuring up to $1,350 \mu$, compared with the normal range in our laboratory of 350 to $800 \mu$. There was oedema of the lamina propria and, in places, a striking outward displacement of the nuclei of individual enterocytes, but there was no evidence of lymphangiectasia or inflammatory bowel disease.

The patient made an uneventful recovery from surgery, but her previous symptoms and signs persisted. Some weeks later, because of recurrent urinary tract infection, an intravenous pyelogram was performed which showed a distorted calyceal pattern in the right kidney, consistent with renal carcinoma. Renal arteriography demonstrated a rather poorly defined tumour circulation. A skeletal survey and isotopic bone scan showed no evidence of metastases. On 2 April a right-sided nephrectomy was carried out.

OPERATIVE FINDINGS (MR CHISHOLM)

A tumour (7 cm diameter) was found in the midportion of the right kidney.

The tumour appeared well defined with no evidence of spread into renal veins, inferior vena cava, or renal pelvis. There was no macroscopic evidence of lymphatic involvement but posteriorly the tumour had extended through the renal capsule and a small lymph node close to the inferior vena cava subsequently proved to contain tumour deposit.

The naked-eye appearance of the small intestine was unchanged from that seen at laparotomy on 22 January. There was an increased intestinal diameter measuring $5 \mathrm{~cm}$ in the jejunum and $3.5 \mathrm{~cm}$ in the lower ileum. Once again, there was massive retention of faeces in the colon.

A surgical biopsy of the lower jejunum showed identical dissecting and light microscopic appearances of villous hypertrophy to those obtained on 22 January (Figs. 2 and 3).

The abdomen was explored and no other tumour was palpated; in particular, the pancreas appeared normal.

\section{Nephrectomy Specimen}

\section{MACROSCOPIC FEATURES}

The cut surface of the right kidney showed a soft, round, yellowish tumour, demarcated from surrounding renal parenchyma by a well defined capsule. There was no haemorrhage or necrosis in the tumour and calcium was present in its periphery, suggesting that it was a slow growing lesion.

\section{LIGHT MICROSCOPY}

The histology of the tumour was not that of a renal carcinoma but strongly suggested an endocrine tumour.

The histological pattern varied from one part of the tumour to the next. In some areas there were islands of small ovoid cells surrounded by a palisade layer of tall cuboidal cells (Fig. 4a) while in other areas there were interlacing and winding ribbons of columnar cells (Fig. 4b). In general, the tumour cells were well differentiated with few mitotic figures. The cells were weakly argyrophil but did not display argentaffinity. The stroma varied in amount and contained numerous capillaries. In places where the renal capsule was invaded the tumour also involved the vascular channels.

\section{ELECTRON MICROSCOPY}

The tumour was composed of light and dark epithelial cells with a basement membrane present where the cells bordered on connective tissue. The nuclei were large, central, and vesicular with marginated chromatin and large prominent nucleoli and the Golgi complex was well developed (Fig. 5).

The most striking feature, however, was the presence of distinctive spherical electron-dense secretory granules measuring $100-200 \mathrm{~m} \mu$ in diam- 


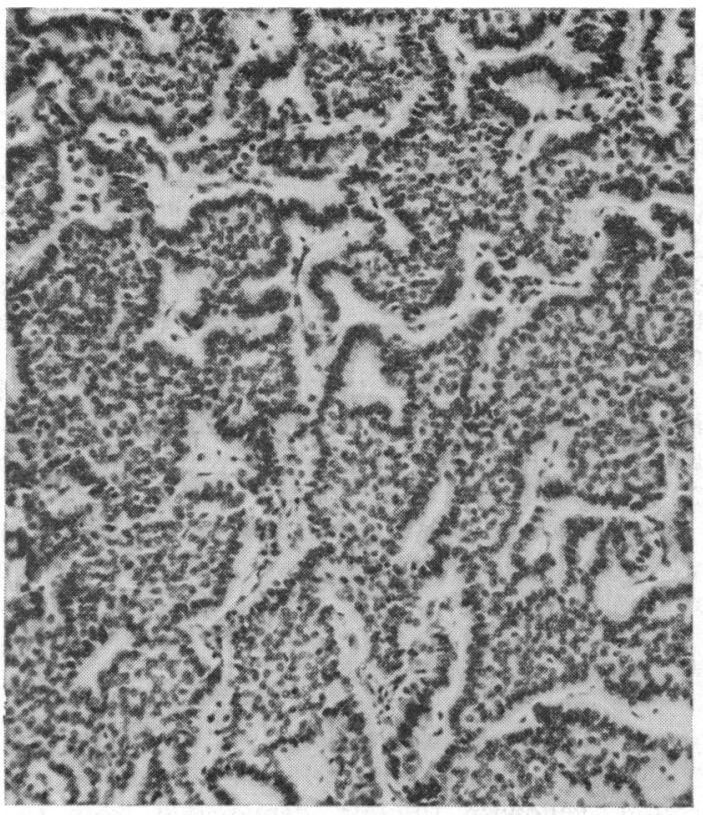

Fig. 4a Solid islands of cells bordered by a palisade layer.

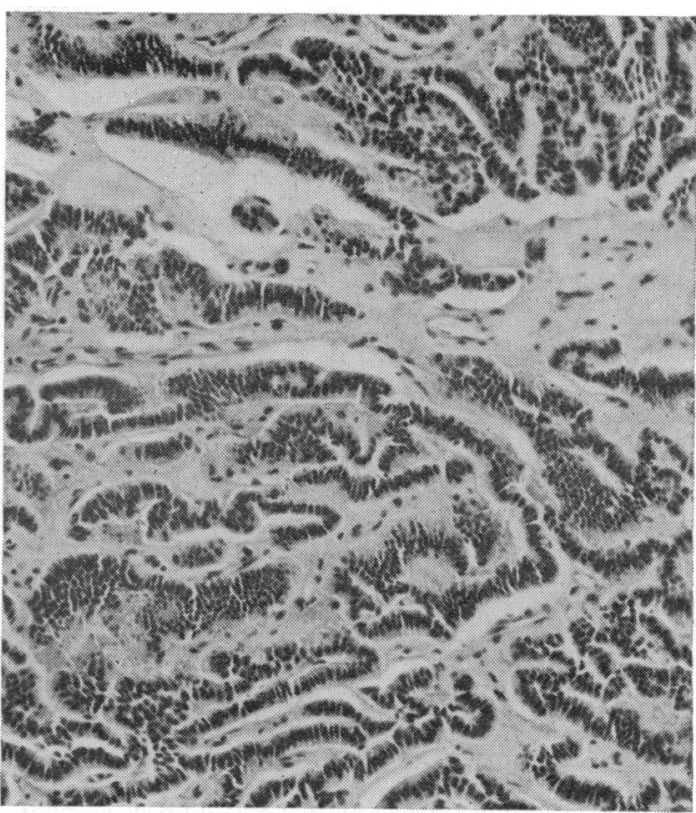

Fig. $4 \mathrm{~b}$ Winding ribbons of columnar cells separated by an abundant stroma $(H \& E \times 120)$.

\section{Fig. 4 Light microscopy of renal tumour.}

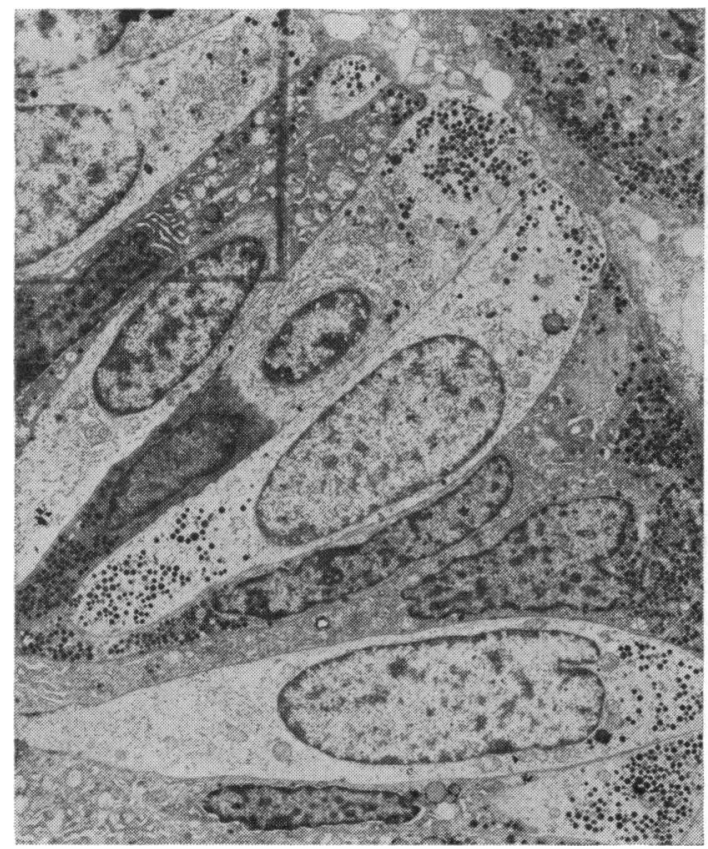

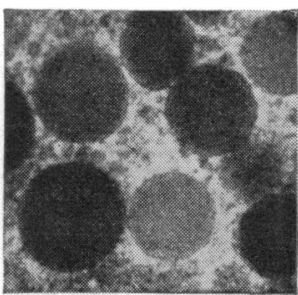

Inset. Secretory granules approximately $200 \mathrm{m \mu}$ with dense homogeneous contents surrounded by a limiting membrane $(\times 50,000)$.

Fig. 5 Electron micrograph of renal tumour epithelial cells bordering the perivascular connexions with secretory granules aggregated at the vascular pole of the cells $(\times 3,250)$. 
eter (Fig. 5 inset). These were most numerous in the palisade layer of cells and showed a polar arrangement in that they tended to be aggregated at the vascular pole of the cells.

\section{HISTOCHEMISTR Y}

The results of the cytochemical studies are given in Table I. The patient's tumour cells fulfilled the classical cytochemical criteria for polypeptide hormone-secreting or APUD cells (Table I). The storage granules in the tumour tissue also stained strongly for tryptophan, suggesting either a carcinoid or pancreatic islet $\alpha_{2}$ cell tumour.
A strongly positive reaction was seen with antiglucagon on tissue sections (Fig. 6). Antisera against gastrin, calcitonin, growth hormone, and ACTH gave no fluorescence. A weak positive reaction was obtained with anti-insulin; this was probably due to impurity, since it is difficult to obtain anti-insulin without some anti-glucagon activity.

\section{RADIOIMMUNOASSAY AND BIOASSAY}

The patient's fasting preoperative plasma immunoreactive glucagon was more than 10 times normal at $6 \mathrm{ng} / \mathrm{ml}$ (the normal immunoreactive glucagon equivalent in the fasting subject is $0.45 \mathrm{ng} / \mathrm{ml}$ ). The

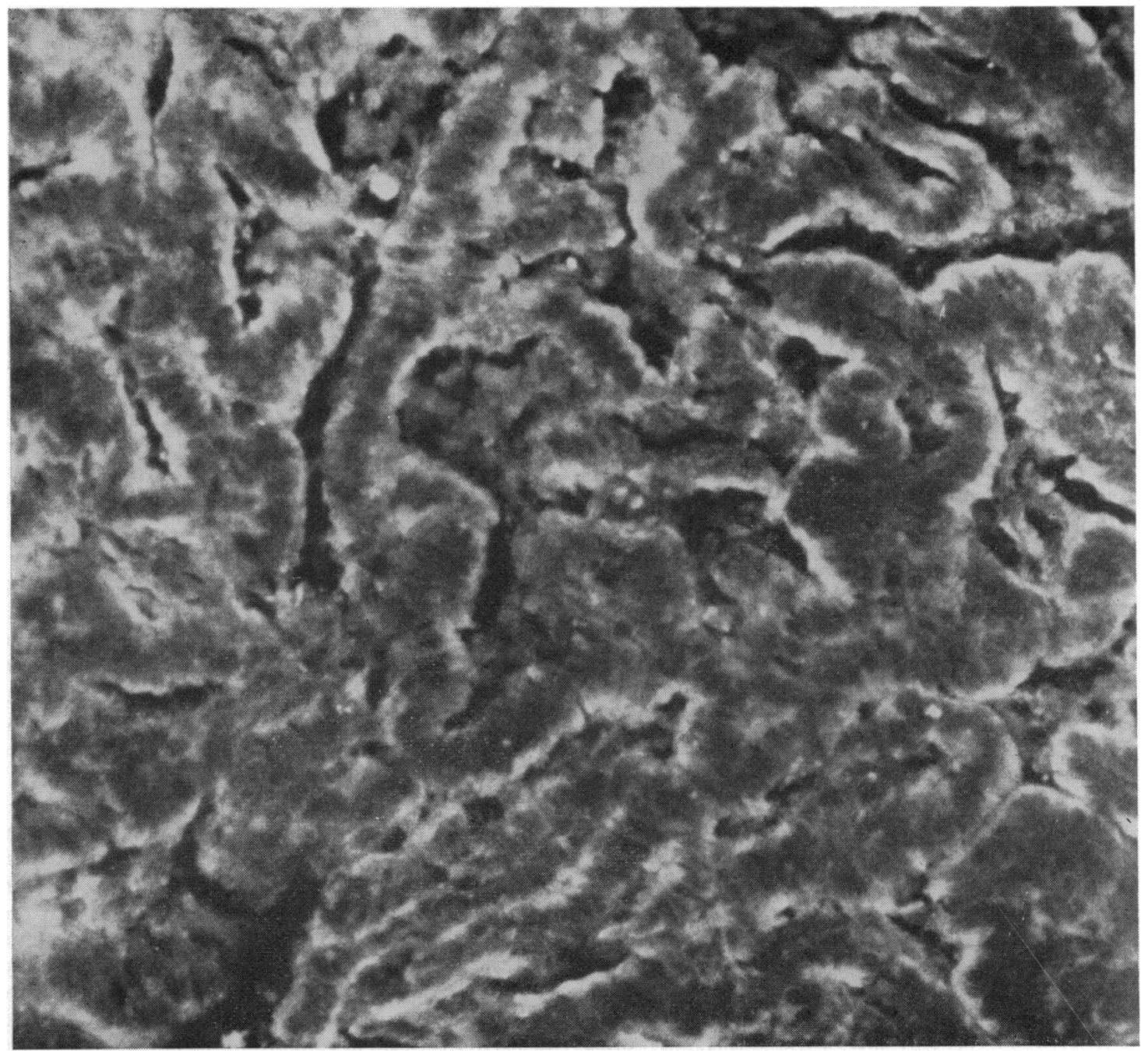

Fig. 6 Immunofluorescence demonstration of glucagon in the renal tumour, showing localization of fluorescence similar to that of secretory granules as shown by electron microscopy $(\times 400)$. 
glucagon content of the tumour, also measured by radioimmunoassay, was $0.15 \mathrm{mg} / \mathrm{g}$ wet weight tissue.

The injected dose of saline tumour extract, which contained $3 \mu \mathrm{g}$ immunoreactive glucagon, produced a marked rise in plasma insulin from the baseline level of $25 \mu \mathrm{U}$ to $110 \mu \mathrm{U} / \mathrm{ml}$ in three minutes. After 10 minutes the injection also produced a sustained rise in plasma glucose from a constant baseline value of $140 \mathrm{mg} / 100 \mathrm{ml}$ to $260 \mathrm{mg} / 100 \mathrm{ml}$, and there was a further rise to $310 \mathrm{mg} / 100 \mathrm{ml}$ over the next 20 minutes.

\section{Progress after Nephrectomy}

After removal of the tumour there was a marked change in the clinical picture. The patient's constipation disappeared almost immediately; in fact, on the second postoperative day she had 12 bowel motions and subsequently she has had a tendency to loose and frequent stools (three to four a day). Hair growth has returned to normal and menstruation has begun again. There was an obvious improvement in the radiological appearances of the intestine, the diameter of the small bowel and the mucosal pattern returning to normal (Fig. 1b). In contrast to the slow intestinal transit before nephrectomy, the barium now traversed the small bowel very rapidly, reaching the colon in 20 minutes. A peroral jejunal biopsy showed that the mucosa had also become normal, with normal villous height and no longer any suggestion of oedema in the lamina propria or epithelial cells. Vitamin $\mathbf{B}_{12}$ absorption, both with and without intrinsic factor, was normal (15.2\%) and the urinary indican excretion had also fallen to normal levels (40 mg/24 hours). Faecal fats, however, have varied from normal levels to values of $12 \mathrm{~g} / 24$ hours. The glucose tolerance test no longer showed a diabetic pattern and was entirely normal.

\section{Discussion}

Glucagon-secreting tumours are extremely rare, and in the few previously reported glucagonomas there have been no consistent clinical features. However, some of the findings in the present patient have been noted previously.

Hyperinsulinism secondary to excess circulating glucagon may present, as in this case, with abnormal glucose tolerance (Unger et al, 1964) or with frank diabetes (McGavran et al, 1966). Mild abnormalities of liver function have been described before by Yoshinaga et al (1966) whose patient with a pancreatic A cell tumour also had secondary amenorrhoea though the mechanism for these clinical features is unknown. Several other unexplained aspects in the present case have also been previously described in glucagonomas, namely, a skin rash, haemolytic anaemia, and oedema. McGavran et al (1966) described a bullous eczematoid dermatitis affecting hands, feet, and legs, and their patient was also noted to have oedema. These authors also described anaemia with increased reticulocytes and a negative Coombs test associated with a glucagon-secreting $a$-cell carcinoma of the pancreas.

The changes in small bowel structure, motility, and absorptive function noted in our patient have not been previously described in association with glucagonoma. In fact, McGavran et al (1966) specifically mentioned that barium studies in their patient showed a normal small bowel. The question arises, therefore, can glucagon (either on its own or possibly in association with other hormones secreted by the tumour) produce the intestinal changes described in this patient? It is known that glucagon increases mesenteric blood flow in dogs (Kock, Tibblin, and Schenk, 1970) but whether increased blood flow stimulates small bowel hypertrophy is clearly unknown. It is, of course, possible that, in addition to glucagon, the tumour was elaborating a second hormone which directly stimulated villous growth. The precedent that a tumour might produce two hormones has been established by Unger et al (1964) who described the production both of insulin and glucagon in metastases from a bronchogenic carcinoma. Furthermore, the concept of an 'intestinal epithelial growth hormone' is not new and was postulated by Loran and Crocker (1963) to explain increased cell turnover (Loran and Althausen, 1960) and intestinal hypertrophy which are seen in the residual small bowel of rats following intestinal resection (Booth, Evans, Menzies, and Street, 1959; Dowling and Booth, 1967). Loran and Carbone (1968) showed by cross-circulation experiments that there was an increased rate of cell turnover in the small intestine of the unoperated rat after resection of the small bowel in its parabiotic mate. However, the experimental data are far from conclusive and there is no direct evidence that such a hormone exists in man.

The constipation which was such a prominent feature in the present patient's symptoms may have been due to glucagon since it is known that glucagon inhibits motility in the human jejunum and colon (Kock, Darle, and Dotevall, 1967). Whether the disturbance in intestinal motility caused by glucagon could produce a blind loop syndrome is open to question. The pattern of absorptive defect seen here with steatorrhoea, vitamin $\mathbf{B}_{12}$ malabsorption, and gross indicanuria is compatible with a stagnant loop picture. Whether hypomotility alone without an associated anatomical defect producing stasis can 
cause a blind loop syndrome in man remains to be proven, although Hershenson (1965) induced fat malabsorption in the human subject by reducing intestinal motility with probanthine. The definitive proof of a blind loop syndrome by aspiration of intestinal juice for quantitative bacteriological and bile salt studies was not possible before surgery in our patient because of difficulties with duodenal intubation.

Another possible explanation for the patient's malabsorption of fat and vitamin $B_{12}$ is exocrine pancreatic insufficiency since it is known that glucagon may inhibit pancreatic exocrine secretion (Dyck, Texter, Lasater, and Hightower, 1970). Although no direct assessment of pancreatic exocrine function was made, pancreatic insufficiency is a less likely explanation for the patient's malabsorption since low rather than high levels of urinary indican excretion would be expected in this situation (Neale, Lambert, and Gorbach, 1969).

The evidence presented in this paper suggests that the tumour was indeed producing glucagon. Light and electron microscopy suggested that the tumour was endocrine in type and the size of the secretory granules seen on electron microscopy were similar to those described in pancreatic A cells. The histochemical findings suggested that the tumour was producing glucagon, either alone or in combination with another polypeptide hormone (or at least, that it was secreting a polypeptide which cross-reacted with anti-glucagon serum). The specificity of both the immunofluorescent studies and the radioimmunoassay depends, of course, on the antiserum used, and in the present studies pancreatic glucagon antiserum was used. It might be argued that if the tumour in the present case were secreting enteroglucagon rather than pancreatic glucagon the antiserum might not cross-react. However, this objection is largely negated by the disappearance of immunofluorescence when the antiserum was absorbed with an excess of the antigen. Furthermore, the bioassay (which is clearly not dependent on antigenic fractions of the molecule) provides convincing proof that the polypeptide secretion was indeed glucagon.

The effects of injecting experimental animals with extracts of tumour and of the patient's preoperative serum on small bowel structure and function are now being studied. In addition, the chemical nature of the polypeptide hormone is being analysed, and the results of these studies will be the subject of further communications.

Photomicrographs by Mr W. Hinkes, Department of Medical Illustration, Royal Postgraduate Medical School. We are grateful to Dr J. Beales and colleagues in the Department of Radiodiagnosis and to
Mr G. Chisholm of the Department of Surgery, Royal Postgraduate Medical School, for their contributions in the management of this case. Dr G. Neale kindly estimated the urinary indicans. We are also grateful to Dr F. W. D. Rost, Professor A. G. E. Pearse, and Professor C. C. Booth for their guidance and helpful criticism. Finally, we thank the Department of Chemical Pathology, Royal Postgraduate Medical School, for their considerable contribution in the investigation of this case.

\section{References}

Albano, J., and Elkins, R. P. (1970). The attainment of high sensitivity and precision in radioimmunoassay techniques as exemplified in a simple assay of serum insulin. In vitro Procedures with Radioisotopes in Medicine. (Proceedings of International Atomic Energy Authority Symposium, Vienna, 1969). pp. 491-513. I.A.E.A., Vienna.

Booth, C. C., Evans, K. T., Menzies, T., and Street, D. F. (1959). Intestinal hypertrophy following partial resection of the small bowel in the rat. Brit. J. Surg., 46, 403-410.

Coons, A. H., Leduc, E. H., and Connolly, J. M. (1955). Studies on antibody production. I. A method for the histochemical demonstration of specific antibody and its application to study of the hyperimmune rabbit. J. exp. Med., 102, 49-60.

Curzon, G., and Walsh, J. (1962). A method for the determination of urinary indoxyl sulphate (indican). Clin. chim. Acta, 7, 657663.

Dowling, R. H., and Booth, C. C. (1967). Structural and functional changes following small intestinal resection in the rat. Clin. Sci., 32, 139-149.

Dyck, W. P., Texter, E. C., Jr., Lasater, J. M., and Hightower, N. C., Jr. (1970). Influence of glucagon on pancreatic exocrine secretion in man. Gastroenterology, 58, 532-539.

Gössner, W., and Korting, G. W. (1960). Metastasierendes Inselzellkarzinom vom A-Zelltyp bei einem Fall von Pemphigus foliaceus mit Diabetes renalis. Dtsch. med. Wschr., 85, 434-437.

Helmer, O. M., and Fouts, P. J. (1937). Gastro-intestinal studies. VII. The excretion of xylose in pernicious anemia. $J$. clin. Invest., 16, 343-349.

Hershenson, L. M. (1965). Impairment of fat absorption by altered intestinal motility. (Abstr.). Gastroenterology, 48, 820-821.

van de Kamer, J. H., ten Bokkel Huinink, H., and Weyers, H. A. (1949). Rapid method for the determination of fat in feces. J. biol. Chem., 177, 347-355.

Kock, N. G., Darle, N., and Dotevall, G. (1967). Inhibition of intestinal motility in man by glucagon given intraportally. Gastroenterology, 53, 88-92.

Kock, N. G., Tibblin, S., and Schenk, W. G., Jr. (1970). Hemodynamic responses to glucagon: an experimental study of central, visceral and peripheral effects. Ann. Surg., 171, 373379.

Laws, J. W., Shawdon, H., Booth, C. C., and Stewart, J. S. (1963). Correlation of radiological and histological findings in idiopathic steatorrhoea. Brit. med. J., 1, 1311-1314.

Loran, M. R., and Althausen, T. L. (1960). Cellular proliferation of intestinal epithelia in the rat two months after partial resection of the ileum. J. biophys. biochem. Cytol., 7, 667-672.

Loran, M. R., and Carbone, J. V. (1968). In Gastrointestinal Radiation Injury, edited by M. F. Sullivan, pp. 127-139. Excerpta Medica Foundation, Amsterdam.

Loran, M. R., and Crocker, T. T. (1963). Population dynamics of intestinal epithelia in the rat two months after partial resection of the ileum. J. Cell Biol., 19, 285-291.

McGavran, M. H. , Unger, R. H., Recant, L., Polk, H. C., Kilo, C., and Levin, M. E. (1966). A glucagon-secreting alpha-cell carcinoma of the pancreas. New Engl. J. Med., 274, 1408-1413.

Neale, G., Lambert, R. A., and Gorbach, S. (1969). The production of indole by bacteria in vitro. Gut, 10, 1056-1057. (Abstr.)

Pearse, A. G. E. (1969). The cytochemistry and ultrastructure of polypeptide hormone-producing cells of the APUD series and the embryologic, physiologic and pathologic implications of the concept. J. Histochem. Cytochem., 17, 303-313.

Polak, J. M. (1971). Unpublished observations. 
Polak, J. M., Bloom, S., Coulling, I., and Pearse, A. G. E. (1971). Immunofluorescent localization of enteroglucagon cells in the gastrointestinal tract of the dog. Gut, 12, 311-318.

Polak, J. M., Coulling, I., Doe, W., and Pearse, A. G. E. (1971), The $G$ cells in pernicious anaemia. Gut, 12, 319-323

Rost, F. W. D., Polak, J. M., and Pearse, A. G. E. (1969). The melanocyte: Its cytochemical and immunological relationship to cells of the endocrine polypeptide (APUD) series. Virchows Arch. [Zellpath.], 4, 93-101.

Schilling, R. F. (1953). Intrinsic factor studies. II. The effect of gastric juice on the urinary excretion of radioactivity after the oral administration of radioactive vitamin $B_{12}$. J. Lab. clin. Med., 42, 860-866.

Solcia, E., Sampietro, R., and Capella, C. (1969). Differential staining of catecholamines, 5-hydroxytryptamine and related com- pounds in aldehyde-fixed tissues. Histochemie, 17, 273-283.

van Tongeren, J. H. M., and Majoor, C. L. H. (1966). Demonstration of protein-losing gastroenteropathy: the disappearance rate ${ }^{61} \mathrm{Cr}$ from plasma and the binding of ${ }^{51} \mathrm{Cr}$ to different serum proteins. Clin. chim. Acta, 14, 31-41.

Unger, R. H., Lochner, J. de V., and Eisentraut, A. M. (1964). Identification of insulin and glucagon in a bronchogenic metastasis. J. clin. Endocr., 24, 823-831.

Vance, J. E., Kitabchi, A. E., Buchanan, K. D., Stoll, R. W. Hollander, D., and Wood, F. C. (1968). Hypersecretion of insulin, glucagon and gastrin in a kindred with multiple adenomatosis. (Abstr.) Diabetes, 17, 299.

Yoshinaga, T., Okuno, G., Shinji, Y., Tsujii, T., and Nishikawa, M. (1966). Pancreatic A-cell tumor associated with severe diabetes mellitus. Diabetes, 15, 709-713. 